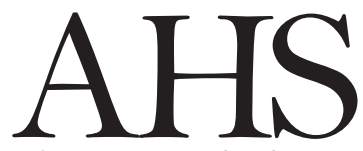

Advances in Horticultural Science

\title{
Reflective benches for improving ligh- ing in residential basil cultivation
}

OPEN ACCESS

\footnotetext{
${ }^{(*)}$ Corresponding author:
}

agrovendruscolo@gmail.com

\section{Citation:}

FERREIRA CAVALCANTE D., PRADI VENDRUSCOLO E., SELEGUINI A., DE CASTRO SERON C., COSTA E., LEANDRO PIRES L., 2021 - Reflective benches for improving lighting in residential basil cultivation. - Adv. Hort. Sci., 35(4): 343-349.

\section{Copyright:}

(C) 2021 Ferreira Cavalcante D., Pradi Vendruscolo E., Seleguini A., de Castro Seron C., Costa E., Leandro Pires $L$. This is an open access, peer reviewed article published by Firenze University Press (http://www.fupress.net/index.php/ahs/) and distributed under the terms of the Creative Commons Attribution License, which permits unrestricted use, distribution, and reproduction in any medium, provided the original author and source are credited.

Data Availability Statement:

All relevant data are within the paper and its Supporting Information files.

Competing Interests:

The authors declare no competing interests.

Received for publication 26 February 2021 Accepted for publication 2 August 2021

\author{
D. Ferreira Cavalcante ${ }^{1}$, E. Pradi Vendruscolo ${ }^{1}(*)$, A. Seleguini ${ }^{2}$, C. de \\ Castro Seron ${ }^{1}$, E. Costa ${ }^{1}$, L. Leandro Pires ${ }^{3}$ \\ 1 Mato Grosso do Sul State University, Rod. MS 306, km 6,4 CEP 79540- \\ 000, Cassilândia, Mato Grosso do Sul, Brazil. \\ 2 Triângulo Mineiro Federal University, Rio Paranaíba Avenue, CEP \\ 38280-000, Iturama, Minas Gerais, Brazil. \\ 3 Agronomy School, Goiás Federal University, Samambaia Campus, \\ Esperança Avenue, CEP 74690-900, Goiânia, Goiás, Brazil.
}

Key words: Cultivation technology, light supplementation, ornamental species, urban cultivation.

Abstract: Light-reflecting covers can help plant development in shaded environments, improving growing conditions in small residential spaces, encouraging the practice of small cultivations of food and ornamental species. Thus, the objective of this work was to evaluate the effect of reflective bench covers on the growth and development of different cultivars of basil, in pot and shaded environment. The treatments consisted of three reflective materials (aluminum thermal reflective mesh, shiny red and white coating on laminates), arranged on the cultivation benches, and two basil cultivars (green and purple). After 22 days under these environments, the number of leaves and nodes, stem diameter, plant height, relative chlorophyll content, fresh and dry masses of the aerial and roots parts were determined. The highest value of reflective photosynthetically active radiation was shown when using white laminate, followed by the red laminate and thermal reflective mesh. The green basil varieties showed higher values for number of leaves, stem diameter, plant height, fresh shoot weight and number of nodes, compared to the purple variety; however, in relation to the relative chlorophyll content, the purple variety was superior. The bright white and red laminate covers positively influence environmental conditions, increasing the reflectance of photosynthetically active radiation, and the development of basil plants in conditions of greater shading.

\section{Introduction}

In view of the urban valorization, the well-lit spaces that could be reserved for the cultivation of ornamental plants, fruits, vegetables, or medicinal plants, have been extinguished in the residences of modern society. With the reduction of the sizes of urban lots, the practice of cultivation continues in inadequate spaces, with little or no direct sunlight, limited in containers, arranged in corridors, balconies, garages and even indoors. 
In the last decades the consumer has been looking for novelties in the area of ornamental plants (Noordegraaf, 2000) and has been attracted by the use of species with unusual aesthetic potential for cultivation in pots. However, the lack of information for the cultivation of some species in residential spaces, causes the inadequate development of plants to occur and culminate in loss of stimulus on the part of the owners.

Basil (Ocimum basilicum L.) belong to the Lamiacea family and it's economic value have being increased due to its multiple uses as aromatic and seasoning species, on pharmaceutical industry, and essential oil production, (Pereira and Moreira, 2011). This species is a vigorous shrub, with potential to also be used as an ornamental, due to its characteristics as the shape of the plant, leaves, flowers, and inflorescences, added to the pleasant aroma and the possibility of direct consumption (França et al., 2017).

Studies with basil have been developed to identify agronomic aspects, chemical compounds for the pharmaceutical and cosmetics industry, among others (Pereira and Moreira, 2011). However, research that seeks to assess the potential of culture for the home environment with some light restriction is incipient.

Light is the main element for photosynthesis to occur, enabling the conversion of light energy into organic energy. Therefore, plant growth and development are affected in a complex way by solar radiation (Taiz et al., 2017). Researches have been carried out to evaluate the responses of plants to light intensity, using parameters such as height, diameter of the neck, dry matter of the aerial part and roots. In a study by Chang et al. (2008) with four levels of solar radiation on basil, there was a reduction in height, weight, leaf area and an intense drop in photosynthesis under $75 \%$ of shading.

In the presence of light, the responses of the plants are mediated by changes depending on the intensity, quality, direction, and duration of the solar incidence and are controlled by specialized photoreceptors (Kami et al., 2010). Photoreceptor proteins have a small cofactor or chromophore molecule, which capture and act at specific wavelengths of light over a specific spectrum (Burgie et al., 2014).

The development of some plants common to domestic cultivation, such as basil, is effectively affected by both the spectrum and the intensity of light that falls on the plant, which can enhance the biometric development and the chemical composi- tion of plant organs (Stagnari et al., 2018). Thus, the implementation of techniques to obtain better conditions for the development of plants is necessary, since shading interferes with the use of solar radiation causing losses in the development of some species (Conforto et al., 2011).

Aiming to obtain concise data and to stimulate the practice of small domestic crops of food and ornamental species cultivation, in environments with low solar incidence, the objective of this work was to evaluate the effect of reflective materials on the growth and development of two basil cultivars potted in a shaded environment.

\section{Materials and Methods}

\section{Location and characterization of the experimental area}

The work was carried out in an urban residential area in the space of a corridor formed between the wall and the house, in the municipality of Cassilândia - MS (19 $10^{\prime} 81^{\prime \prime} \mathrm{S} ; 51^{\circ} 73^{\prime} 44^{\prime \prime} \mathrm{W}$ and average altitude of $540 \mathrm{~m}$ ), from October to December 2019. According to the Köppen climate classification, the region's climate is humid tropical (Aw) with an average annual temperature of $29^{\circ} \mathrm{C}$. During the conduction of the experiment, the climatic data were collected in a meteorological station present in the municipality (Fig. 1).

The space presented between the wall $(2.20 \mathrm{~m}$ high) and the house wall ( $6.50 \mathrm{~m}$ high) in the dimensions ( $1.45 \mathrm{~m}$ wide and $6.20 \mathrm{~m}$ long) forms an open corridor, which receives at least 3 hours of sunlight during the morning (Fig. 2). This environment does not include a source of artificial lighting, the color of the walls of the house being white and the ceramic brick wall in natural color.

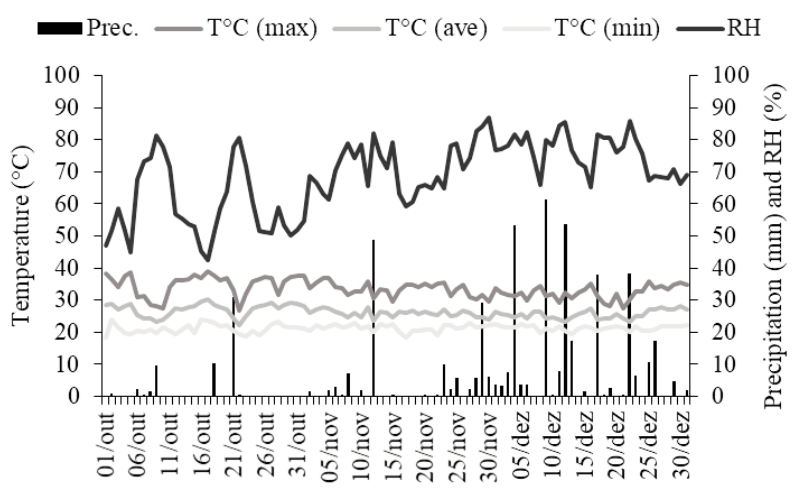

Fig. 1 - Summary of climatic conditions during the experiment. 


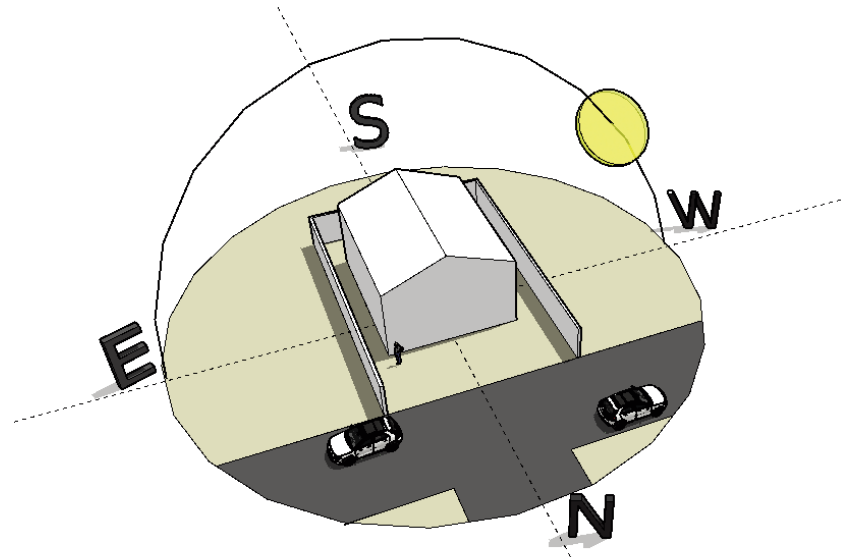

Fig. 2 - Location of the residential corridor used for the domestic cultivation of basil (Ocimum basilicum L.) plants in a pot according to the solar orientation.

\section{Experimental design}

A completely randomized design was used to evaluate the reflective materials, with six treatments and eight repetitions, each pot being one repetition. The treatments were composed of three reflective materials arranged on the cultivation bench (thermal reflective mesh, bright red laminate sheet; bright white laminate sheet) and two varieties of basil Ocimum basilicum L. (sweet basil - green leaf and purple basil - purple leaf), both from the manufacturer Feltrin".

\section{Implementation and conduction of the experiment}

The experiment was installed and conducted on benches made with reused wood pallets, in the dimensions of $0.40 \mathrm{~m}$ width, $1.20 \mathrm{~m}$ length and 0.90 $\mathrm{m}$ height, spaced $0.70 \mathrm{~m}$ apart from each other and covered with the three different reflective materials. These same materials were fixed on the walls of the house, in a vertical direction, with dimensions $0.50 \mathrm{~m}$ $x 1.20 \mathrm{~m}$.

The seedlings were produced in expanded polystyrene trays of 200 cells, filled with commercial substrate CarolinaSoil ${ }^{\circ}$ at the experimental area. Following the recommendations of the manufacturer, the depth for sowing was $0.5 \mathrm{~cm}$, both for green and purple basil. The emergence occurred 5 days after sowing, thus thinning the seedlings leaving only one per cell and 26 days after sowing the transplant was carried out to the black flexible PVC pots with a capacity of $1 \mathrm{~L}$, being manually irrigated two times a day.

After 22 days, the relative chlorophyll content in the leaves, the number of leaves, plant height, stem diameter, the number of nodes, fresh and dry weight of the aerial part and roots were evaluated.

The plant height, in centimeters, was determined from the level of the substrate in the pots to the inflection of the highest leaf. The stem diameter, in millimeters, was measured from the base of the stem using a digital caliper. The relative chlorophyll content was obtained using a portable digital chlorophyll meter SPAD-502 (Minolta Camera Co. Ltd.), determined from the third or fourth mature leaf and completely expanded, starting from the apex of each plant.

To obtain fresh weight, the plants were cut close to the substrate, divided into aerial part and roots and weighted. The determination of the dry weight of the aerial part and root the plants were dried in an oven with forced air circulation at $65^{\circ} \mathrm{C}$ for 72 hours.

Microclimatic data of the cultivation environment were collected between 9 am and 10 am on different sunny days, with the Apogee model MP-200 measuring the reflected PAR $\left(\mu \mathrm{mol} \mathrm{m} \mathrm{m}^{-2} \mathrm{~s}^{-1}\right)$ of each material (treatment) with the sensors facing the bench at a height of $30 \mathrm{~cm}$ and the incident environmental PAR $\left(\mu \mathrm{mol} \mathrm{m} \mathrm{m}^{-2} \mathrm{~s}^{-1}\right)$.

\section{Statistical analysis}

The data were submitted to analysis of variance (Test F) and the averages were compared by the Tukey test, at $5 \%$ probability. The analyzes were performed using the statistical software Sisvar ${ }^{\circ}$ version 5.6 for Windows (Ferreira, 2014).

\section{Results and Discussion}

It was found that the reflected radiation was higher when using white laminate sheet (Fig. 3), which reflected about $12.67 \%$ of the total radiation, followed by the thermal reflective mesh (TRM) and red

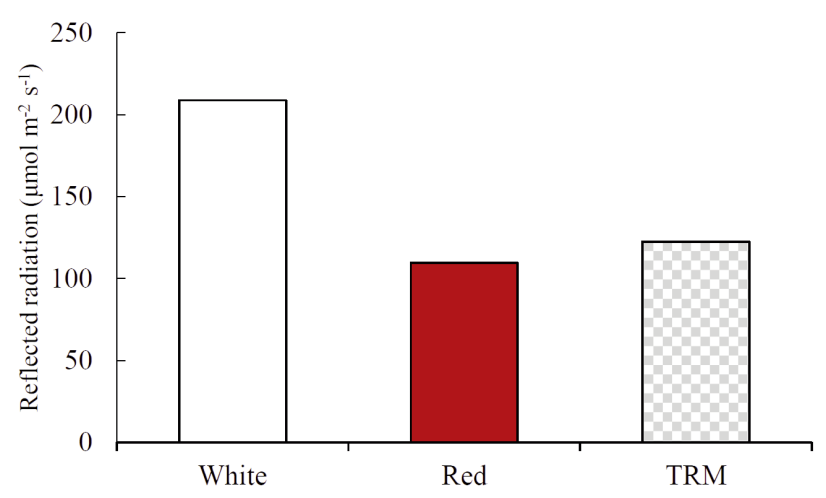

Fig. 3 - Reflected radiation of with different bench covers, from an environmental incident radiation of $1910 \mu \mathrm{mol} \mathrm{m} \mathrm{m}^{-2} \mathrm{~s}^{-1}$. 
laminate sheet, with $7.01 \%$ and $6,09 \%$, respectively.

The interaction between the two factors studied (cultivars $x$ bench covers) on the growth attributes of basil was not verified ( $p>0.05)$. However, there was a significant effect, both for the type of bench used ( $p>$ $0.05)$ and for the varieties ( $p>0.05$ ).

Regardless of the cultivars, basil plants grown on thermal reflective mesh had lower number of leaves, stem diameter, plant height, relative chlorophyll content, fresh and dry aerial weight than plants grown using white and red laminate sheets (Fig. 4). However, the dry root mass did not vary between different materials. Proportionally, these reductions were on average $33.48 \%, 15.32 \%, 12.88 \%, 20.70 \%$, $13.98 \%$ and $35.67 \%$ respectively, for the number of leaves, stem diameter, plant height, relative chlorophyll content, fresh weight and dry weight of aerial parts, compared to the combined average of white and red laminate sheets (Fig. 4).

The gains in biometric characteristics when using bright white laminate sheet may be related to the quality of light, Antonopoulou et al. (2004) state that white light is a rearrangement of colors including blue and red. These wavelengths are those used by plants for the process of photosynthesis, as well as physiological process.

The number of leaves was affected by cover material used, so that plants grown in the environment with bright white and red laminate sheets had a high-
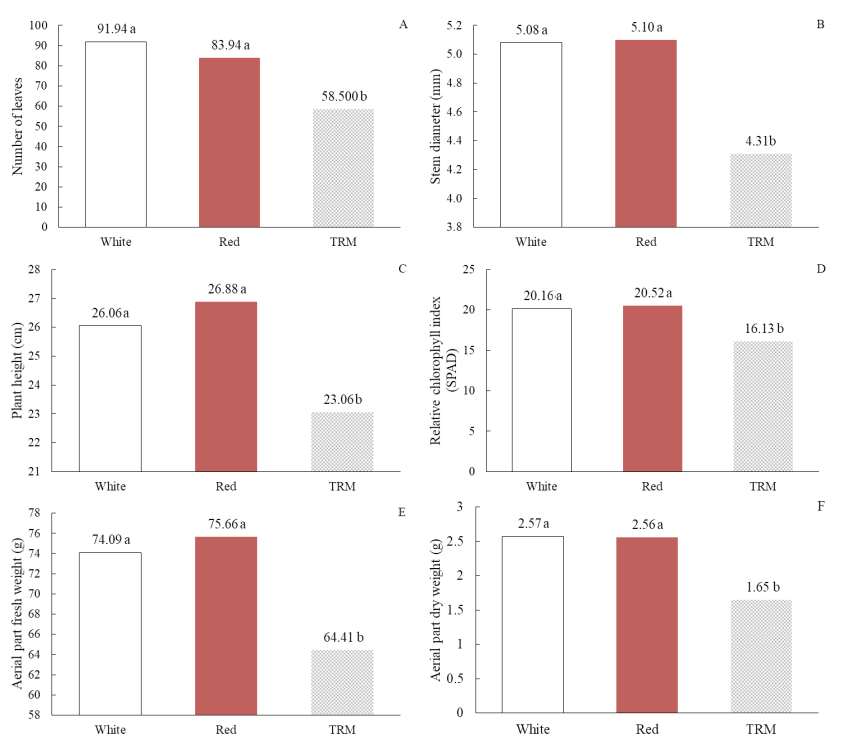

Fig. 4 - Number of leaves (A), stem diameter (B), plant height (C), relative chlorophyll content (D) fresh weight of the aerial part (E) and dry weight of roots (F) of green and purple basil (Ocimum basilicum L .), grown in pots in a domestic environment, with different bench covers. er number of leaves in relation to the thermal reflective mesh. Therefore, it can be inferred that basil plants are responsive to the quality of light under the conditions evaluated.

In the cultivation of Pereskia aculeata, Vieira (2017) obtained a lower number of leaves under red mesh in relation to the pearl mesh, which is a variation of the white color, showing different results from that found in the present work.

Differences were verified for the stem diameter as a function of the materials used. The thermal reflective mesh provided the lowest value, when compared to the bright white and red laminate sheets. Larger stem diameter is a desirable characteristic in seedlings because it guarantees greater support for the aerial part, when these plants are exposed to adverse wind or intense rain conditions (Souza et al., 2014).

The growth pattern of basil plants varied according to the environments to which they were submitted. Plants exposed to colored laminate sheets had greater height when compared to those on thermal reflective mesh but there was no significant difference between white and red laminate sheet.

In a study by Souza et al. (2014) evaluating the growth of rosemary plants under colored meshes and in full sun, found a greater height of plants when cultivated in full sun, attributing to this the high luminous intensity and the characteristics of the species. This corroborate with what was observed in the present study, when the high radiation reflected by the white laminate sheet was verified, increasing the total radiation on plant tissues (Fig. 4). Although the red laminate sheet reflected a lower percentage of radiation, it yielded results similar to those of the white laminate sheet, which possibly has a relationship with the quality of the reflected light.

The growth in terms of stem diameter and plant height and higher chlorophyll content in the leaves showed greater gains in the colored laminate sheets, compared to the thermal reflective mesh, indicating that there was no etiolation. According to Taiz et al. (2017), etiolated plants have long hypocotyls, a hooked apex, and non-photosynthetic leaves.

Henrique et al. (2011), studying the development of coffee seedlings under cover with colored meshes, blue, white, gray, black and red, with shading of $50 \%$, found that the red one was more efficient in promoting growth in plant height, area and leaf dry matter mass and total dry matter mass. In the present study with basil, it was possible to observe that, there was 
no difference between the white and red laminate sheets, in the variable plant height.

For the relative chlorophyll the plants placed on the bench covered with thermal reflective mesh had a lower value, which indicates the low capacity of this material to reflect the FRG. The SPAD index (Soil Plant Analysis Development) is used to diagnose the nitrogen status of crops, an element related to plant growth and productivity (Pôrto et al., 2011) and related to the photosynthetic condition (Dinh et al., 2019).

Costa et al. (2012), evaluating the vegetative growth of peppermint seedlings in five environments, full sun and under black, aluminized, blue and red meshes, all with $50 \%$ irradiance, observed superior gains in leaf dry weight, stem and shoot biomass under full sun, red and black mesh respectively, when compared to other cultivation environments. Paulus et al. (2016) found similar results when cultivating basil under a photoconverting mesh, finding a greater accumulation of fresh and dry mass of the aerial part in full sun, in relation to the red and aluminized mesh. Divergent results were found in the present study, which showed a greater accumulation of fresh weight of the aerial part in plants grown on white and red laminate sheet.

Basil is a heliophyte species and according to Silva (2014) it is considered efficient at high radiation intensities, which promotes better photosynthetic activity. The reflected radiation when using white laminate sheet was higher than that observed for the red one, however, no results were obtained in the accumulation of fresh biomass from the aerial part, which may be also associated with the quality of the light reflected by the materials used.

The aerial part dry weight of the basil plants was affected by the use of the cover materials (Fig. 4F). Plants grown with the use of bright white and red laminate sheets showed a higher dry weight of the aerial part, in relation to the thermal reflective mesh. Melo and Alvarenga (2009), evaluating the effect of radiation in full sun condition and by covering with red, blue and black meshes, in Catharanthus roseus L. G. Don vinca plants, found greater increases in dry weight using the red material.

Sunlight is like a shower of photons and plays an essential role in photosynthesis, the process of transforming light energy into chemical energy. Wave spectra have different roles in plants. Blue light (400$500 \mathrm{~nm}$ ) promotes root growth and intense photosynthesis. The red light that comprises the light range between (600-700 $\mathrm{nm}$, provides increases in the accumulation of dry mass, lengthening of the stem and expansion of the leaf area in addition to improvements in photosynthetic activity. The photoreceptors that promote morphogenic changes in plants are those capable of to absorb blue and red light, with phytochrome being responsible for the absorption of these spectra (Taiz et al., 2017).

Despite the lower proportion of radiation reflected by the red laminate sheet, this did not prevent the plants grown in this environment from accumulating an equal amount of dry weight from the aerial part to that of the plants when grown on white laminate sheet. This demonstrates that plants have the ability to modify their development model in response to the luminous environment (Larcher, 2004).

Plants have a specificity regarding the wavelength received due to the absorption spectrum determined by the photosynthetic pigments present in the chloroplast. The absorption spectrum determines the amount of light energy captured or absorbed by a molecule or substance as a function of the wavelength received. In this sense, the reflective materials arranged on the benches promote better use of radiation by reflecting the luminosity of the environment on the leaf's abaxial face (Lima et al., 2018).

Studying the effect of red light emitting diode (LED) lamps on grapes, Poudel et al. (2008) found greater optimization of photosynthesis, directly influencing the height of the aerial part, length of internodes and rooting frequency, however, it is noteworthy the need for blue light for chlorophyll synthesis and stomatal activity. Lima et al. (2010) evaluating the growth of Anthurium andraeanum Apalai under colored meshes with $70 \%$ shading found that the black mesh provided better growth conditions in relation to the blue, red and thermal reflective mesh.

Among basil varieties, it was observed that for the variables of leaf number, stem diameter, plant height, fresh shoot weight and number of nodes, the plants of the green variety were $144.20 \%$ higher, $34.95 \%, 35.59 \%, 4.76 \%$ and $20.91 \%$, respectively, in relation to the purple variety. However, in relation to the relative chlorophyll content, the purple variety was $12.0 \%$ higher (Fig. 5).

Lin et al. (2020) investigating the response of purple and green basil when subjected to different proportions of red, blue and green light, found a greater increase in height, leaf area and stem diameter in green basil plants compared to purple. This shows the influence of the environmental conditions 

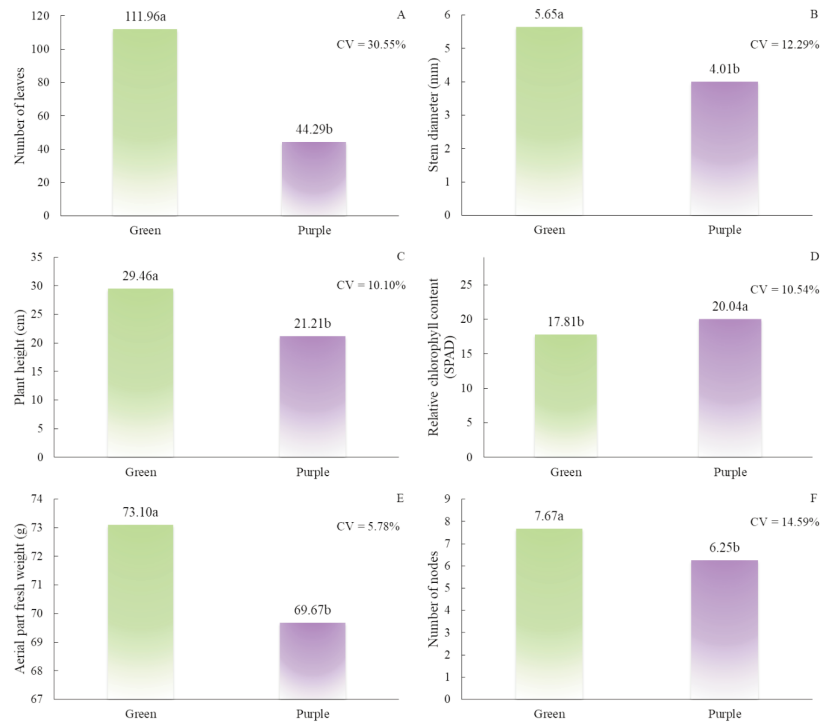

Fig. 5 - Number of leaves (A), stem diameter (B), plant height (C), relative chlorophyll content (D), aerial fresh weight (E) and number of nodes (F) between green and purple basil cultivars (Ocimum basilicum L.) grown in pots in a domestic environment, with different bench covers.

imposed on the growth and development of the plants. The results found by the authors are similar to the present study, where there was interference from the environment and the genotype in the growth and development of plants.

The accumulation of dry weight in the aerial part and roots was also higher in plants of the green variety, about $52.51 \%$ and $83.64 \%$, respectively, in relation to plants of the purple variety (Fig. 6). The differences between the genotypes of basil used in the present study were expected due to species great genetic diversity, not only morphological, but also in terms of the characteristic compounds of the species,

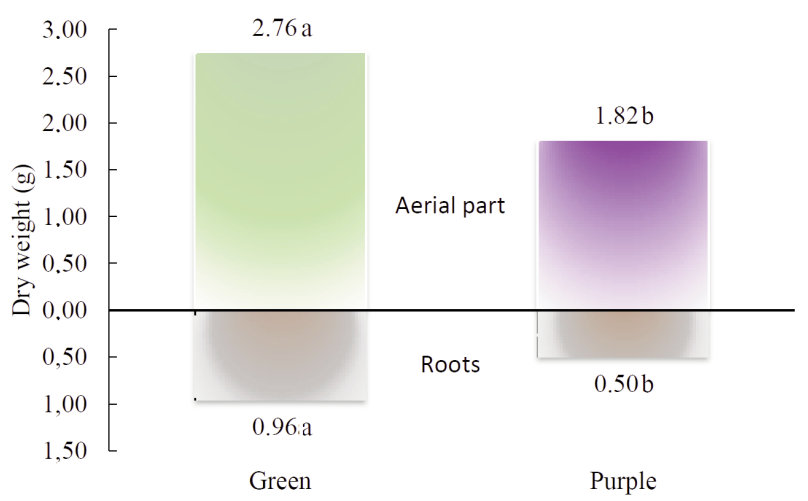

Fig. 6 - Dry weight of the aerial part and roots between green and purple basil cultivars (Ocimum basilicum L.), cultivated in pots in a domestic environment, with different bench covers. such as essential oils (Blank et al., 2010; Veloso et al., 2014; Castro et al., 2016).

The cultivation of plants in homes is a custom passed down from generation to generation. However, due to the growth of urban areas and the consequent reduction of spaces for cultivation, there is a need for innovative techniques that provide better conditions for the development of plants, especially in environments with less incidence of light. In this sense, the use of colored materials on countertops in cultivation environments is a technique that has been studied and has shown positive results in this new model, as demonstrated in the present study.

The use of colored benches in low solar radiation places provides better conditions for the growth and development of basil plants very similar and/or superior to the cultivation carried out in the absence of shading, according to a study by Souza et al. (2011). According to the authors, the accumulation of dry weight of plants grown with substrate in full sun was less than the values of the present study.

Based on the results of the present study, and in view of the characteristics of cultivation in domestic spaces, it is inferred preference for the use of white coloring, due to the characteristic of providing greater luminosity to the environment, in addition to the aesthetic enhancement of the vegetables, with contrast provided between the plants and the bench. In addition, concerning the cultivation of basil, the use of a white or red cover favors the development of plants due to the greater reflectance of photosynthetically active radiation. In this way, both colors can be used for the cultivation of this species in shaded environments.

\section{References}

ANTONOPOULOU C., DIMASSI K., THERIOS I., CHATZISSAVVIDIS C., 2004 - The influence of radiation quality on the in vitro rooting and nutrient of peach rootstock. Biologia Plantarum, 48(4): 549-553.

BLANK A.F., DE SOUZA E.M., DE PAULA J.W., ALVES P.B., 2010 - Comportamento fenotípico e genotípico de populações de manjericão. - Horticultura Brasileira, 28: 305-310.

BURGIE E.S., BUSSELL A.N., WALKER J.M., DUBIEL K., VIERSTRA R.D., 2014 - Crystal structure of the photosensing module from a red/far-red light-absorbing plant phytochrome. - Proceedings of the National Academy of Sciences, 111(28): 10179-10184.

CASTRO H.G., VELOSO R.A., CARDOSO D.P., CHAGAS 
JÚNIOR A.F., CHAGAS L.F.B., 2016 - Characterization botanical-agronomic and essential oil of basil accessions. - Revista Verde de Agroecologia e Desenvolvimento Sustentável, 11(4): 1-6.

CHANG X., ALDERSON P.G., WRIGHT C.J., 2008 - Solar irradiant ce level alters the growth of basil (Ocimum basilicum L.) and its content of volatile oils. - Environ. Exper. Bot., 63: 216-223.

CONFORTO E.C., BITTENCOURT JÚNIOR N.S., SCALOPPI JÚNIOR E.J., MORENO R.M., 2011 - Comparação entre folhas sombreadas de sete clones adultos de seringueira. - Revista Ceres, 58(1): 29-34.

COSTA A.G., CHAGAS J.H., PINTO J.E.B.P., BERTOLUCCI S.K.V., 2012 - Crescimento vegetativo e produção de óleo essencial de hortelã-pimenta cultivada sob malhas. - Pesquisa Agropecuária Brasileira, 47(4): 534540.

DINH T.H., TAKARAGAWA H., WATANABE K., NAKABARU M., KAWAMITSU Y., 2019 - Leaf photosynthesis response to change of soil moisture content in sugarcane. Sugar Tech, 21(6): 949-958.

FERREIRA D.F., 2014 - Sisvar - a Guide for its boots rap procedures in multiple comparisons. - Ciência e Agrotecnologia, 38(2): 109-112.

FRANÇA M.F.M.S., VILELA M.S., COSTA A.P., NOGUEIRA I., PIRES M.C., SOUZA N.O.S., 2017 -Germination test and ornamental potential of diferente basil cultivars (Ocimum spp.). - Ornamental Horticulture, 23(4): 385391.

HENRIQUE P.C., ALVES J.D., DEUNER S., GOULART P.F.P., LIVRAMENTO D.E., 2011 - Aspectos fisiológicos do desenvolvimento de mudas de café cultivadas sob telas de diferentes colorações. - Pesquisa Agropecuária Brasileira, 46(5): 458-465.

KAMI C., LORRAIN S., HORNITSCHEK P., FANKHAUSER C., 2010 - Light-regulated plant growth and development. - Current Topics in Developmental Biology, 91: 29-66.

LARCHER W., 2004 - Ecofisiologia vegetal. - Vol. I São Carlos, SP, RiMA Artes e Textos, pp. 531.

LIMA J.D., NOMURA E.S., FUZITANI E.J., SILVA S.H.M.G., 2010 - Variáveis fisiológicas de antúrio cultivado sob diferentes malhas de sombreamento. - Scientia Agraria, 11(3): 193-200.

LIN K.H., HUANG M.Y., HSU M.H., 2020 - Morphological and physiological response in green and purple basil plants (Ocimum basilicum) under different proportions of red, green, and blue LED lightings. - Scientia Horticulturae, 275(3).

MELO A.A.M., ALVARENGA A.A., 2009 - Sombreamento de plantas de Catharanthus roseus (L.) G. Don 'Pacifica White' por malhas coloridas: desenvolvimento vegeta- tivo. - Ciência e Agrotecnologia, 33(2): 514-520.

NOORDEGRAAF C.V., 2000 - An approach to select new ornamental crops. - Acta Horticulturae, 541: 75-78.

PAULUS D., VALMORBIDA R., FERREIRA S.B.; ZORZZI I.C., NAVA G.A., 2016 - Biomassa e composição do óleo essencial de manjericão cultivado sob malhas fotoconversoras e colhido em diferentes épocas. - Horticultura Brasileira, 34(1): 46-53.

PEREIRA R.C.A., MOREIRA A.L.M., 2011 - Manjericão: cultivo e utilização. - Embrapa Agroindústria Tropical, Fortaleza, Brazil, pp.31.

PÔRTO M.L., PUIATTI M., FONTES P.C.R., CECON P.R., ALVES J.C., ARRUDA J.A., 2011 - Índice SPAD para o diagnóstico do estado de nitrogênio na cultura da abobrinha. - Horticultura Brasileira, 29(3): 311-315.

POUDEL P.R., KATAOKA I., MOCHIOKA R., 2008 - Effect of red-and blue-light-emitting diodes on growth and morphogenesis of grapes. - Plant Cell, Tissue and Organ Culture, 92(2): 147-153.

SILVA D.F., 2014 - Utilização de malhas de sombreamento coloridas na produção de mudas e frutos de espécies do gênero Physalis L. - M.S. Thesis. Lavras Federal University, Brazil, pp. 64.

SOUZA G.S., SILVA J.S., OLIVEIRA U.C., SANTOS NETO R.B., SANTOS A.R., 2014 - Crescimento vegetativo e produção de óleo essencial de plantas de alecrim cultivadas sob telas coloridas. - Bioscience Journal, 30(1): 232239.

SOUZA N.H., CARNEVALI T.O., RAMOS D.D., SCALON S.P.Q., MARCHETTI M.E., VIEIRA M.C., 2011 -Produção de mudas de manjericão (Ocimum basilicum L.) em diferentes substratos e luminosidades. - Revista Brasileira Plantas Medicinais, 13(3): 276-281.

STAGNARI F., DI MATTIA C., GALIENI A., SANTARELLI V., D'EGIDIO S., PAGNANI G., PISANTE M., 2018 -Light quantity and quality supplies sharply affect growth, morphological, physiological and quality traits of basil. - Industrial Crops and Products, 122: 277-289.

TAIZ L., ZEIGER E., MOLLER I.M., MURPHY A., 2017 Fisiologia e desenvolvimento vegetal. Vol. VI. Artmed, Porto Alegre, Brazil, pp. 888.

VELOSO R.A., CASTRO H.G., BARBOSA L.C.A., CARDOSO D.P., CHAGAS JÚNIOR A.F., SCHEIDT G.N., 2014 - Teor $e$ composição do óleo essencial de quatro acessos e duas cultivares de manjericão (Ocimum basilicum L.). Revista Brasileira de Plantas Medicinais, 16: 364-371.

VIEIRA J.S., 2017 -Propagação vegetativa, crescimento e teor de proteína em ora-pro-nóbis Pereskia aculeata Miller - cultivado sob telas fotosseletivas. - M.S. Thesis, Federal Institute of Education, Science and Technology of Goias, Brazil, pp. 64. 
